\title{
LIMITES CONSTITUCIONAIS À CONCESSÃO DE ISENÇÕES FISCAIS
}

\section{CONSTITUTIONAL LIMITS TO THE GRANTING OF TAX EXEMPTIONS}

\author{
Nilson Roberto da Silva Gimenes ${ }^{1}$
}

\section{RESUMO}

Este artigo analisa teoricamente as isenções tributárias através de uma abordagem sistemática e como os parâmetros estabelecidos pela Constituição podem servir para a interpretação e aplicação equilibrada das normas concessivas de isenções fiscais pelos órgãos administrativos e judiciais de julgamento dos processos tributários, inclusive com estudos de casos selecionados da jurisprudência.

Palavras-chave: Isenções Fiscais. Limites Constitucionais. Interpretação.

\begin{abstract}
This article theoretically analyzes tax exemptions through a systematic approach and how the parameters established by the Constitution can serve for the interpretation and balanced application of tax exempting rules by the administrative and judicial organs of judgment of the tax proceedings, including with selected case studies of the case-law.
\end{abstract}

Key words: Tax exemptions. Constitutional limits. Interpretation.

\footnotetext{
${ }^{1}$ Professor da UNEB - Universidade do Estado da Bahia, Campus XIX - Camaçari. Doutor e Mestre em Direito Público pela UFBA - Universidade Federal da Bahia.
} 


\section{INTRODUÇÃO}

As isenções tributárias são um importante instrumento da política econômica dos poderes públicos estatais das três esferas da Federação. Elas precisam estar adequadas às balizas constitucionais e do Código Tributário Nacional (CTN), para que possam ser aplicadas sem correrem o risco de serem anuladas por decisão judicial. Este trabalho discutirá, portanto, sobre os limites jurídicos para a concessão das isenções.

Primeiramente, breves notas sobre a cláusula do devido processo legal no direito tributário brasileiro serão feitas, com enfoque voltado para a análise dos aspectos procedimental e substantivo do princípio, e de como ele foi considerado em algumas decisões judiciais, por ser um princípio que influencia toda a disciplina do direito tributário.

O capítulo seguinte avançará numa discussão mais específica sobre a disciplina das isenções, considerando aspectos do CTN pertinentes ao tema, e se estas configuram ou não privilégios para os particulares no regime constitucional estabelecido. Também exporá os tipos de isenções que guardam considerável relevância para o estudo do assunto, inclusive as isenções veiculadas por tratados internacionais e como são aplicadas no direito brasileiro.

Outro capítulo trará a discussão de alguns casos decididos em tribunais superiores a respeito dos limites para a concessão de isenções, em alguns com admissão da norma de isenção e em outros com anulação. Os casos selecionados terão relação com certas discussões teóricas travadas nos primeiros capítulos. Com isso, recorrer-se-á às fontes primárias da jurisprudência, o que evitará um estudo apenas doutrinário dos limites para as isenções.

O trabalho utiliza fontes bibliográficas e decisões da jurisprudência. Por conta disso, o método indutivo, com o estudo desses casos, é utilizado para a resolução do problema proposto, que é como podem ser aplicados os limites constitucionais para a 


\section{Ti= REVISTA ACADÊMICA FACULDADE DE DIRETIO DO RECIFE}

JSS N: $2448-2307$

concessão de isenções, além de se fazer uma abordagem sistemática na apreciação teórica do tema.

O estudo do tema se justifica pela sua importância prática. Por conta das desigualdades regionais e do subdesenvolvimento de vários setores da economia, muitas normas de isenções são elaboradas pelos legisladores das três esferas federativas, o que pode abrir espaço para a concessão não muito criteriosa delas. Por isso, será desenvolvido o tema proposto.

\section{BREVES NOTAS SOBRE O DEVIDO PROCESSO LEGAL TRIBUTÁRIO}

A formulação do conceito "devido processo legal" se desenvolveu na Magna Carta, de 1215, que buscou selar um pacto entre o Rei João e os barões. O artigo 39 estabeleceu que "nenhum homem será detido ou preso, nem privado de seus bens, banido ou exilado ou, de algum modo, prejudicado, nem agiremos ou mandaremos agir contra ele, senão mediante um juízo legal de seus pares ou segundo a lei da terra" (grifos do autor) ${ }^{2}$.

O significado do dispositivo acima é objeto de controvérsia. Para alguns, o objetivo era simplesmente determinar que as pessoas fossem devidamente notificadas, pudessem apresentar sua defesa e fossem julgadas pela autoridade competente. Para outros, o objetivo era mais amplo: foi dada uma sinalização de que os privilégios concedidos pela Magna Carta e outros instrumentos medievais não poderiam ser restringidos de forma aleatória pelo rei. Tal restrição só poderia ocorrer precedida de rito específico (juízo legal de pares) e em conformidade com a lei da terra ${ }^{3}$.

No período medieval a lei da terra estava intimamente associada à ideia de direito costumeiro, que decorria da sedimentação de decisões passadas, em especial de decisões

\footnotetext{
2 VIEIRA, Oscar Vilhena. Direitos Fundamentais: uma leitura da jurisprudência do STF. São Paulo: Malheiros, 2006, p. 474.

${ }^{3}$ Ibid., p. 474, 475.
} 
judiciais. No início do século XVII, o Lorde Coke, em vários casos, decidiu pela supremacia do direito costumeiro, impedindo que alguma instituição se fizesse de juiz em causa própria. E em 1765, o influente jurista William Blackstone declarou que "atos do parlamento contrários à razão não são válidos”. Assim, o devido processo designava o estabelecimento de um juízo imparcial e estava associada aos limites substantivos ao exercício da autoridade ${ }^{4}$.

Na esfera tributária brasileira, a Constituição Federal determinou não apenas que a lei seja prospectiva (art. 150, III, “a”), mas que também não surpreenda os indivíduos por assegurar o princípio da anterioridade. Não se pode cobrar tributo "no mesmo exercício financeiro em que haja sido publicada a lei que os instituiu ou aumentou" (art. 150, III, "b") 5 .

O devido processo legal é também observado através de outras garantias. O princípio do "juiz natural" impede a escolha ad hoc de juízo. E as garantias da "ampla defesa" e do "contraditório" se estendem aos processos administrativos, consignando a livre manifestação das partes envolvidas e determinando a realização de procedimento equânime e honesto ${ }^{6}$.

O princípio da legalidade na ordem constitucional não se esgota na exigência de regulação legal estatal das condutas dos indivíduos. A lei deve respeito à Constituição, que sustenta valores como o princípio da igualdade. Assim, as diferenciações porventura criadas pelas leis não devem ser desnecessárias e nem arbitrárias ${ }^{7}$.

Outro aspecto que merece análise em relação à cláusula do devido processo legal é que o sistema de tributação deve salvaguardar o contribuinte de excessos (substantive due process) ou abusos na cobrança (procedural due process). Em síntese, quer-se a exação equitativa. Neste respeito, infelizmente, a legislação brasileira está desatualizada perante os desafios da realidade, o que compromete a efetivação do princípio. A necessidade de reorganização do sistema fiscal se justifica pelo presente alto custo para as empresas, pela dificuldade de compreensão da legislação e para tornar reais as

\footnotetext{
${ }^{4}$ Ibid., p. 475, 476.

${ }^{5}$ Ibid., p. 487.

${ }^{6}$ Ibid., p. 491.

${ }^{7}$ Ibid., p. 486.
} 


\section{HIIII REVISTA ACADÊMICA FACULDADE DE DIRETIO DO RECIFE}

garantias do contribuinte ${ }^{8}$.

Por mais imparciais que sejam os procedimentos democráticos para a tomada de decisões, não se deve desconsiderar que estas afetem os direitos fundamentais. Assim, é necessário que um órgão não majoritário, como é o poder judiciário, tenha o poder de julgar pela impugnação de atos violadores dos direitos individuais. Portanto, a cláusula em seu aspecto substantivo é realizadora do próprio Estado de Direito ${ }^{9}$. Por conta da importância do poder judiciário para tal mister, alguns casos da jurisprudência serão analisados a seguir.

O primeiro caso é um recente em que se discutiu a aplicação do princípio do devido processo legal no direito tributário foi o Agravo Regimental no Agravo Regimental no Recurso Extraordinário no 719.800-DF, relatado pelo Ministro Celso de Mello e julgado em 11 de junho de 2013. A União não conseguiu o provimento do recurso de $\operatorname{agravo}^{10}$.

No recurso extraordinário acima foi decidido que era necessária a prévia notificação do contribuinte excluído do Programa de Recuperação Fiscal (REFIS), para que se observasse a plenitude de defesa e o contraditório. A inconstitucionalidade do artigo $1^{\circ}$ da Resolução CG/REFIS 20/2001, declarada pelo Tribunal a quo, foi confirmada. A publicação via internet da exclusão do REFIS/PAES não atendeu ao devido processo. Era necessária a instauração regular de processo administrativo. Ninguém pode ser privado de seus bens ou de seus direitos sem a observância do devido processo legal, inclusive em sede materialmente administrativa, sob pena de nulidade da própria medida restritiva de direitos.

O Superior Tribunal de Justiça (STJ) também tem analisado o princípio. No Recurso Especial no 478.853-RS, interposto pelo Conselho Regional de Administração do Rio Grande do Sul, ficou decidido que o contribuinte precisa ser notificado do ato de

\footnotetext{
${ }^{8}$ NOGUEIRA, Alberto. O devido processo legal tributário. Rio de Janeiro: Renovar, 1995, p. 13, 59.

${ }^{9}$ Ibid., p. $482,483$.

${ }^{10}$ BRASIL. Supremo Tribunal Federal. Agravo Regimental no Agravo Regimental no Recurso Extraordinário n $^{\mathbf{0}}$ 719.800/DF. Relator: Min. Celso de Mello. Julgamento: 11/06/2013. Brasília: Supremo Tribunal Federal, 2013. Disponível em: $<$ http://www.stf.jus.br/portal/jurisprudencia/listarJurisprudencia.asp?s1=\%28719800\%2ENUME\%2E $+\mathrm{O}$ U+719800\%2EACMS\%2E\%29\&base=baseAcordaos\&url=http://tinyurl.com/nmkc463> Acesso em: 21 jun. 2016.
} 
lançamento que a ele respeita. Se tal não ocorrer, o lançamento e a execução fiscal nele fundada serão nulos. A ampla defesa e o contraditório, corolários do devido processo, são de observância obrigatória inclusive no procedimento administrativo. O Recurso não foi provido $^{11}$.

O Recurso Especial $n^{\circ}$ 478.853-RS estabeleceu a necessidade de notificação do contribuinte do ato de lançamento que a ele respeita. A importância deste caso é que ele evidencia que a legitimidade do lançamento não se presume e o ato de lançamento não é autoexecutável, pois pode ser impugnado pelo sujeito passivo em processo administrativo.

Outro recurso especial julgado pelo STJ foi o de $\mathrm{n}^{\mathrm{o}} 463.418$, interposto pelo INSS, que buscou a responsabilização de tomadora de serviços pelas dívidas lançadas apenas contra a prestadora de serviços, em sede de execução fiscal. Só que o instituto da solidariedade não é capaz de legitimar o redirecionamento de execução fiscal já em curso contra pessoa jurídica em relação à qual não foi sequer lançado o débito tributário, pois a solidariedade deve ser observada no momento do lançamento. Invocou-se o devido processo legal - o contribuinte deve ter a oportunidade de impugnar o lançamento, apresentar provas que repute cabíveis, dentre outras providências. Por fim, o STJ diferenciou o redirecionamento da execução fiscal contra o administrador pelos débitos da empresa, ainda que seu nome não esteja na Certidão da Dívida Ativa (CDA), quando ocorrer alguma das hipóteses previstas no artigo 135 do $\mathrm{CTN}$, do caso em tela. O recurso foi desprovido ${ }^{12}$.

A Câmara Superior de Recursos Fiscais (CSRF), do Ministério da Fazenda, também examinou o princípio em casos vitoriosos para os contribuintes. Sua Terceira Turma, no Processo $n^{\text {o }}$ 10830.000059/96-02, entendeu que a rejeição, pelo Fisco, do primeiro método para apuração do Valor Aduaneiro - Valor de Transação, deve ser

${ }^{11}$ BRASIL. Superior Tribunal de Justiça. Recurso Especial no 478.853-RS. Relator: Min. Luiz Fux. Julgamento: 10/06/2003. Publicado DJ 23/06/2003. Brasília: Superior Tribunal de Justiça, 2003. Disponível em:

$<$ https://ww2.stj.jus.br/processo/revista/documento/mediado/?componente=ITA\&sequencial=412622\&nu $m$ registro $=200201342185 \&$ data $=20030623 \&$ formato $=P D F>$ Acesso em: 21 jun. 2016

${ }_{12}$ BRASIL. Superior Tribunal de Justiça. Recurso Especial no 463.418-SC. Relator: Min. Denise Arruda. Julgamento: 21/11/2006. Publicado DJ 18/12/2006. Brasília: Superior Tribunal de Justiça, 2006. Disponível 
precedida pelo devido processo investigatório, conforme o artigo $1^{\circ}$ do Acordo sobre a Implementação do artigo VII do Acordo Geral sobre Tarifas Aduaneiras e Comércio (GATT). Não se admite presunção da infração de subfaturamento - ela deve ser comprovada. A Fazenda Nacional teve seu recurso especial negado, confirmando-se a nulidade do auto de infração lavrado contra a empresa ${ }^{13}$.

O auto de infração descreveu que a falta de recolhimento do Imposto de Importação (II) e do Imposto sobre Produtos Industrializados (IPI) ocorreu por conta do valor de transação incorreto. Só que o subfaturamento foi "verificado" pela discrepância entre o valor de transação declarado na Declaração de Importação objeto do litígio e suas respectivas Guias de Importação, e o valor que se encontrava especificado nas demais Declarações de Importação e Guias de Importação mencionadas pela fiscalização, relativas a importações da mesma mercadoria, realizadas na mesma época. Os inúmeros embarques parciais das mercadorias, todos em datas próximas, referiram-se à mesma transação comercial efetuada entre empresas vinculadas, levadas a efeito por remessas fracionadas.

Porém, tal atitude da fiscalização foi precipitada, pois ela teria de adotar o necessário procedimento legal antes de promover a autuação, ao invés de passar diretamente à autuação, utilizando o segundo método de apuração do valor aduaneiro, promovendo a exigência de diferença de tributos e aplicando penalidades. $\mathrm{O}$ auto de infração foi anulado, o que maculou todas as demais fases do processo administrativo. Assim, ficou estabelecia a necessidade de se adotar os procedimentos cabíveis para a correta apuração do valor de transação da mercadoria envolvida e, se fosse também o caso, o subfaturamento alegado.

Em outro processo, o de $\mathrm{n}^{\mathrm{o}} 10830.005479 / 2002-21$, a $1^{\mathrm{a}}$ Turma da CSRF decidiu pelo não provimento do recurso especial interposto pela Fazenda Nacional, que queria tornar válida lavratura de auto de infração contra pessoa jurídica extinta. O caso não foi de incorporação de uma pessoa jurídica em outra, mas de pessoa extinta que se tornou

13 BRASIL. Ministério da Fazenda - Câmara Superior de Recursos Fiscais. Processo no 10830.000059/96-02. Relatora: Anelise Daudt Prieto. Julgamento: 20/02/2006. Brasília: Câmara Superior de Recursos $\quad$ Fiscais, $2006 . \quad$ Disponível em: $<$ https://carf.fazenda.gov.br/sincon/public/pages/ConsultarJurisprudencia/listaJurisprudenciaCarf.jsf $>$ Acesso em: 21 jun. 2016. 


\section{REVISTA ACADÊMICA FACULDADE DE DIRETIO DO RECIFE}

inexistente juridicamente. A pessoa jurídica só subsiste até o final de sua liquidação, assim não é possível promover depois o lançamento, bem como a transferência do polo passivo tributário no curso do processo administrativo a um dos sócios da empresa sem o devido processo para identificação do responsável, com a garantia da ampla defesa e do contraditório $^{14}$.

Estas breves considerações sobre o devido processo legal tributário evidenciam que, tanto no que diz respeito à não violação das normas legais que estabelecem isenções fiscais, quanto em relação à necessidade de se evitar a concessão de perdulárias isenções que comprometam a arrecadação e a realização do projeto constitucional de bem-estar social, deve ser observado o princípio do devido processo legal, tanto em sua forma procedimental, quanto em sua forma substantiva.

\section{DISCIPLINA JURÍDICA DAS ISENÇÕES FISCAIS}

Neste passo da pesquisa convém observar que o Direito, diferente das ciências naturais, segue o princípio da imputação: dado certo antecedente normativamente previsto, um descritor normativo, deve-se seguir certo consequente, um prescritor normativo. Sobre a construção da ciência jurídica, é fundamental o método da corroboração empírica. O discurso científico jurídico é uma metalinguagem vertida sobre outro discurso, o da linguagem do objeto, ou seja, a da ordenação jurídico-positiva. Quem lhe fornece a base experimental é a ordem jurídica; o marco referencial objetivo das asserções doutrinárias que a descrevem ${ }^{15}$.

Uma das grandes preocupações da ciência do Direito é a noção de relação jurídica. No Direito Tributário corresponde a (a) uma relação entre quem é competente para criar

14 BRASIL. Ministério da Fazenda - Câmara Superior de Recursos Fiscais. Processo no 10830.005479/2002-21. Relator: Antônio Carlos Guidoni Filho. Julgamento: 09/03/2009. Brasília: Câmara Superior de Recursos Fiscais, $2009 . \quad$ Disponível em: $<$ https://carf.fazenda.gov.br/sincon/public/pages/ConsultarJurisprudencia/listaJurisprudenciaCarf.jsf $>$ Acesso em: 21 jun. 2016.

${ }^{15}$ BORGES, José Souto Maior. Obrigação Tributária. 2a ed. São Paulo: Malheiros, 1999, p. 20, 21, 86, 87. 
a norma tributária e quem é para aplicá-la; (b) uma relação entre o habilitado para a criação e aplicação da norma e aquele a quem essa norma atribui dever ou confere direito; (c) uma relação entre os titulares da competência para a execução de atos coativos e os destinatários desses atos coativos. A relação jurídica tributária não é uma relação de vida extrinsecamente regulada por normas jurídicas, "como se fosse um conteúdo vestido pela forma jurídica", mas é a própria forma, consiste assim, numa relação que somente é estruturada por normas jurídicas ${ }^{16}$.

Há uma relação jurídica entre o poder que isenta e o sujeito beneficiado pela isenção. Porém, nas hipóteses de isenção não há, a rigor, crédito tributário, dado que este não passa de um direito-reflexo da obrigação tributária. Por isso, não há também obrigação tributária nos casos de isenção. O artigo 175 do CTN implicitamente contemplou hipótese de exclusão de obrigação. O legislador não deve regular o fenômeno da incidência para não invadir o campo descritivo da doutrina. Somente com essa reserva a isenção pode ser considerada hipótese de exclusão do crédito tributário ${ }^{17}$.

O Direito Tributário, tanto na regulação do poder de tributar, quanto no poder de isentar, obedece estritamente ao princípio constitucional da legalidade. Tributos e isenções são criados por lei e não podem ser suprimidos por atos infralegais, sob pena de violação do princípio do devido processo. Além disso, as leis devem ser elaboradas de acordo com os procedimentos estabelecidos na Constituição e em atendimento aos direitos fundamentais.

Observados os princípios e normas constitucionais, qualquer tributo pode ser objeto de isenção, não se restringido, portanto, aos impostos. Porém, acentuando o caráter de excepcionalidade das isenções de taxas e contribuições de melhoria, o CTN dispõe, no artigo 177, que salvo disposição de lei em contrário, a isenção não é extensiva às taxas e às contribuições de melhoria ${ }^{18}$.

Sendo a Constituição instrumento de ordenação do Estado democrático de direito, em posição privilegiada no sistema jurídico, e capaz de subordinar todas as demais

\footnotetext{
${ }^{16}$ BORGES, José Souto Maior. Lançamento Tributário. $2^{a}$ ed. São Paulo: Malheiros, 1999, p. 51, 52, 54.

${ }^{17}$ Ibid., p. 72, 73.

${ }^{18}$ BORGES, José Souto Maior. Teoria Geral da Isenção Tributária. $3^{\text {a }}$ ed. São Paulo: Malheiros, 2001, p. 274.
} 
normas que lhe vêm abaixo ${ }^{19}$, é de se concluir que a mesma é a fonte por excelência dos direitos individuais, que não podem ser suprimidos por leis inferiores.

Os direitos fundamentais cumprem a função de direitos de defesa por estabelecerem normas limitativas para a atuação do Poder Público na vida das pessoas e por exigir que tal Poder se abstenha de agredir com lesão aos direitos de liberdade. Têmse, assim, os aspectos negativo e positivo da liberdade ${ }^{20}$.

Os parâmetros formais de aferição da constitucionalidade consistem nos princípios da legalidade, da irretroatividade e da anterioridade. $\mathrm{O}$ primeiro informa que a lei deverá ser a única fonte de cognição no direito brasileiro habilitada à instituição ou aumento de tributos (através da majoração da alíquota ou da ampliação da base de cálculo). O segundo impossibilita a retroação da lei para alcançar atos praticados em período anterior à sua vigência, salvo nos casos autorizados por lei. O terceiro impõe que a norma tributária só deve entrar em vigor no exercício financeiro seguinte ${ }^{21}$.

Vários são os critérios materiais de aferição da constitucionalidade. O primeiro deles é o da capacidade contributiva, que deve estar atrelada ao pressuposto de fato do tributo. Ou seja, deve ser levado em consideração o que o sujeito pode pagar de acordo com sua riqueza e com as condições da sua região. Porém, o critério deve ser objetivo, e esse princípio não é aplicável às taxas e à contribuição de melhoria, porque estas são de caráter retributivo. Pode ou não ser aplicado às contribuições especiais e ao empréstimo compulsório, a depender da finalidade das mesmas. Por exemplo, tal princípio se aplica às contribuições interventivas ${ }^{22}$.

Outro critério material é o da isonomia. A racionalidade exigida por este princípio no direito tributário é teleológica. Deve haver correspondência entre o fator que desiguala e a situação de diferenciação. A finalidade buscada deve estar de acordo com o texto constitucional, além do respeito ao requisito formal da legalidade, o que implica que não pode ato infralegal estabelecer os critérios de desigualdade ${ }^{23}$.

\footnotetext{
${ }^{19}$ BASTOS, Celso Ribeiro. Curso de Direito Constitucional. 14 ed. São Paulo: Saraiva, 1992, p. 44.

${ }^{20}$ CANOTILHO, J. J. Gomes. Direito Constitucional e Teoria da Constituição. $4^{\mathrm{a}}$ ed. Coimbra: Almedina, 1997, p. 401.

${ }^{21}$ PIMENTA, Paulo Roberto Lyrio. Contribuiçães de intervenção no domínio econômico. São Paulo:

Dialética, 2002, P. 86, 87.

${ }^{22}$ Ibid., p. 88-91.

${ }^{23}$ Ibid., p. 94, 95.
} 
As isenções, portanto, não configuram transgressões ao princípio da igualdade tributária, pois elas excetuam os isentos da regra da generalidade da tributação, a fim de que seja obedecido o princípio da isonomia, desde que a isenção normatizada tenha compatibilidade com o sistema constitucional da tributação ${ }^{24}$.

O princípio da razoabilidade é um critério para evitar restrições excessivas de direitos fundamentais. O juízo de razoabilidade é subjetivo e visa impedir o absurdo, mesmo que, por hipótese, não se viole a isonomia. Só com a análise de cada caso concreto que se pode constatar a observância do princípio ${ }^{25}$.

O princípio da proporcionalidade dá um passo à frente em relação à razoabilidade, pois possibilita a concordância prática entre bens prestigiados constitucionalmente. Os passos para a aplicação do mesmo são: a adequação, em que deve haver correspondência entre a medida adotada e o fim almejado; a necessidade, em que se deve analisar qual a medida menos restritiva aos direitos fundamentais; e a proporcionalidade em sentido, em que se realiza o juízo de ponderação para que não ocorra o sacrifício de princípios constitucionais $^{26}$.

A disciplina das isenções tributárias está indissoluvelmente vinculada à exigência da proporcionalidade e da equidade da tributação. Se o pagamento de tributos é obrigação de caráter geral e se todos são iguais perante o fisco, mostram-se inadmissíveis as isenções que importem em meros favores, porque violadoras da generalidade e igualdade da tributação ${ }^{27}$, além de desproporcionais por não atenderem aos requisitos da adequação, necessidade e conformidade (proporcionalidade em sentido estrito), acima expostos.

O princípio da preservação do núcleo essencial do direito visa à concordância prática entre direitos constitucionais. No direito tributário, tal ideia está atrelada à proibição de tributo com efeito confiscatório. O núcleo essencial é o conteúdo que não

\footnotetext{
${ }^{24}$ BORGES, José Souto Maior. Teoria Geral da Isenção Tributária. $3^{a}$ ed. São Paulo: Malheiros, 2001, p. $46,47$.

${ }^{25}$ PIMENTA, Paulo Roberto Lyrio. Contribuições de intervenção no domínio econômico. São Paulo: Dialética, 2002, p. 95, 96.

${ }^{26}$ Ibid., p. 97, 98.

${ }^{27}$ BORGES, José Souto Maior. Teoria Geral da Isenção Tributária. $3^{a}$ ed. São Paulo: Malheiros, 2001, p. 62
} 
deve ser eliminado de um dado direito subjetivo. Visa-se então evitar o excesso e o desrespeito ao mínimo vital ${ }^{28}$.

O princípio da finalidade se aplica aos casos em que o legislador deve apontar quais são os fins visados pelo tributo, o que se aplica às contribuições interventivas e ao empréstimo compulsório. O princípio do destino da arrecadação informa as contribuições de modo geral e o empréstimo compulsório ${ }^{29}$.

Ao atribuir competência para tributar, a Constituição não apenas permite, mas às vezes programa a abstenção do exercício dessa competência pela via da isenção, em certas circunstâncias excepcionais. Também ela estabelece princípios, como os da legalidade, da isonomia, da justiça e da segurança, que vinculam a legislação integrativa ordinária e complementar na disciplina das isenções ${ }^{30}$.

O princípio da proporcionalidade, já mencionado, pode ser muito útil para se analisar se a norma legal que concede isenção atende os critérios constitucionais. A isenção precisa ser o meio adequado para se atingir uma finalidade socialmente vantajosa, deve atender ao requisito da necessidade e estar conforme com os princípios constitucionais, não prejudicando o conjunto dos direitos fundamentais estabelecidos na Constituição. Numa ordem voltada para a realização dos direitos humanos, o legislador tributário precisa levar em conta como realizar os direitos humanos através da tributação, e não apenas considerar os aspectos econômicos envolvidos no fenômeno tanto da tributação como da isenção.

A ordem constitucional brasileira remeteu o problema da regulação das isenções à legislação ordinária e avocou a determinação dos critérios que devem presidir ao estabelecimento de isenções. Não existe isenção sem lei que a determine. A necessidade de verificações, que procedam à expedição do ato administrativo de reconhecimento da existência dos requisitos para o deferimento da isenção, liga-se às exigências de controle fiscal, a fim de que o regime legal não seja fraudado na sua execução ${ }^{31}$.

\footnotetext{
${ }^{28}$ PIMENTA, Paulo Roberto Lyrio. Contribuições de intervenção no domínio econômico. São Paulo: Dialética, 2002, p. 100-102.

${ }^{29}$ Ibid., p. 103, 105.

${ }^{30}$ BORGES, José Souto Maior. Teoria Geral da Isenção Tributária. $3^{\text {a }}$ ed. São Paulo: Malheiros, 2001, p. 31,32 .

${ }^{31}$ BORGES, José Souto Maior. Teoria Geral da Isenção Tributária. $3^{\text {a }}$ ed. São Paulo: Malheiros, 2001, p. $34,35,38,40$.
} 
Em decorrência do princípio da reserva de lei, não se converte o fato gerador em fato isento. Se isso ocorresse, a norma que estabelecesse a isenção estaria a rigor em contradição com a norma que definisse o fato gerador da obrigação tributária, e duas proposições normativas contraditórias não poderiam ser ambas válidas. A norma de isenção é de caráter excepcional e por conta disso não está abrangida pela norma genérica da tributação ${ }^{32}$.

Questiona-se se a isenção não seria um privilégio legal. Mas não instituem privilégios as normas que resguardam abstratamente determinada classe de relações, coisas ou pessoas, precisamente porque o maior ou menor âmbito de aplicação do preceito não vulnera a generalidade do princípio. Só haveria privilégio se a isenção fosse concedida com referência exclusiva à condição das pessoas, ou relacionadas com as classes de tais pessoas ${ }^{33}$.

O problema das isenções extrafiscais conduz à indagação da sua idoneidade para exercer a função de instrumento a serviço de uma política econômico-social (estímulo fiscal). Isso acentua a questão de sua legitimidade perante a Constituição devido à possibilidade de violação do princípio da isonomia fiscal. Por isso, há quem recomende a sua substituição por uma política de subsídios, pois as isenções não possibilitam o cálculo seguro dos custos e embaraçam a competição entre empresas. Porém, genericamente falando, as isenções tributárias a indústrias novas, concedidas a título de incentivo, são plenamente compatíveis com o sistema constitucional da tributação e não ofendem ao princípio da isonomia fiscal ${ }^{34}$.

A inserção das isenções na lei tributária material possibilita, em parte, a previsão orçamentária da receita em cada exercício; a previsão do produto da arrecadação dos diferentes tributos. E, assim como a lei orçamentária, que não pode conter dispositivo estranho à previsão da receita e à fixação da despesa (não pode revogar tributos, só pode autorizar a arrecadação dos mesmos), também a lei orçamentária não pode suprimir ou ampliar isenções, necessariamente estabelecidas na lei tributária material ${ }^{35}$.

\footnotetext{
${ }^{32}$ Ibid., p. 163.

${ }^{33}$ Ibid., p. 65,66 .

${ }^{34}$ Ibid., p. 71, 74, 75.

${ }^{35}$ Ibid., p. 92.
} 
A regra do artigo $5^{\circ}$, XXXVI, da Constituição de 1988, resguardando o direito adquirido, o ato jurídico perfeito e a coisa julgada, é incompatível com lei revogatória que retire discricionariamente vantagem econômica para cujo gozo o beneficiário praticou todos os atos ou prestou os fatos que lhe foram exigidos, sob o risco de se vulnerar o princípio da segurança jurídica. Aplicar a lei revogadora antes do término do prazo para o qual foi deferida a isenção equivale a aplicar retroativamente a lei nova: a que reduziu ou encerrou o prazo de duração ao benefício ${ }^{36}$.

Ainda no tema da revogabilidade, o CTN, além do reconhecimento a contrario sensu das isenções incondicionais, em que não se exigem obrigações correlatas do beneficiário, consagra as isenções condicionais, que são concedidas em certas condições, e das isenções por prazo certo (transitórias) ou por prazo indeterminado (permanentes). Quanto ao regime jurídico-formal da exclusão do crédito tributário, é ainda admitida a isenção contratual (artigos 176 e 178, combinados). Para a sua irrevogabilidade, não basta tenha sido a isenção condicionada. É preciso que ela esteja submetida cumulativamente a (I) condição e (II) prazo certo de vigência ${ }^{37}$.

A isenção, enquanto instrumento de exoneração do pagamento de tributos, pode se referir a pessoas, coisas e atos. Ela pode ser estruturada legalmente em função de circunstâncias materiais (objetivas) ou pessoais (subjetivas) do isento. Também ela modifica ora o âmbito material de validade (isenção objetiva), ora o âmbito pessoal de validade das normas tributárias (isenção subjetiva). Estas últimas não incidem sobre o fato isento ${ }^{38}$.

Nas isenções condicionadas de forma suspensiva, antes da complementação do ciclo formativo do fato gerador da isenção, existe a obrigação tributária, precisamente porque ainda não incidiu a regra jurídica de isenção até que se verifiquem todos os elementos necessários à composição do suporte fático da regra mencionada ${ }^{39}$.

A extinção da isenção ocorre quando ela desaparece do sistema tributário. Diversamente, a perda consiste na circunstância de determinada pessoa, até então isenta,

\footnotetext{
${ }^{36}$ Ibid., p. 78, 79, 81 .

${ }^{37}$ Ibid., p. 79,83 .

${ }^{38}$ Ibid., p. 155,160 .

${ }^{39}$ Ibid., p. 194.
} 


\section{TH REVISTA ACADÊMICA FACULDADE DE DIRETIO DO RECIFE}

ser excluída do gozo ou desfrute da isenção. Enquanto a extinção pode afetar qualquer classe de isenções, a perda afeta apenas as isenções subjetivas ${ }^{40}$.

A isenção objetiva exclui o âmbito material da tributação, o aspecto objetivo do fato gerador (hipótese de incidência). Nas isenções subjetivas, a lei, com uma disposição de direito excepcional, exonera do pagamento do tributo certas pessoas, compreendidas entre os sujeitos passivos da obrigação tributária. A isenção subjetiva, em regime de solidariedade, não é obstáculo para que surja obrigação para outros sujeitos não isentos, participantes do fato tributável. Afirmar, porém, que a isenção é subjetiva quando determinada pessoa é excluída à tributação não nega que as isenções objetivas também beneficiam certas pessoas. A norma jurídica de isenção subjetiva visa direta ou imediatamente aos bens, atos, fatos ou situações que, na sua ausência, estariam submetidos ao tributo, porque é ditada em função de considerações pessoais ${ }^{41}$.

No que diz respeito às obrigações acessórias, pode ocorrer que a lei estabeleça isenção da obrigação tributária principal, persistindo, porém, os deveres instrumentais. Toda isenção deve ser concedida mediante prova documental da sua causa que remova as contestações e incertezas. Mesmo nas isenções objetivas, o Fisco, para fins de controle, pode exigir obrigações acessórias do sujeito beneficiado. Também é importante dizer que o ato administrativo de reconhecimento da existência e autorização do gozo da isenção é meramente declaratório de situação jurídica preexistente por força de lei; ato plenamente vinculado e sem nenhum conteúdo discricionário ${ }^{42}$.

Postas todas essas considerações sobre a disciplina jurídica das isenções, cabe complementar o conteúdo com considerações sobre as isenções de direito internacional. As limitações decorrentes do direito internacional tributário, com o consequente efeito inibitório sobre a competência para a tributação, podem, ao lado dos princípios de direito interno, afetar o regime das isenções. Por exemplo, as chamadas "imunidades diplomáticas" configuram verdadeiramente isenções, são em geral subjetivas e decorrentes de tratados internacionais ${ }^{43}$.

\footnotetext{
${ }^{40}$ Ibid., p. 195.

${ }^{41}$ Ibid., p. 258, 261, 262, 267.

42 Ibid., p. 335-337.

${ }^{43}$ Ibid., p. 238, 239.
} 
As isenções tributárias decorrentes de tratados ou convenções internacionais não poderão afetar o regime jurídico interno da tributação antes de serem ratificados. As isenções reconhecidas pelo direito internacional podem basear-se - e geralmente isso ocorre - na regra da reciprocidade. A lei interna pode condicionar a isenção, por exemplo, para evitar a bitributação internacional, à reciprocidade de tratamento por parte de Estado estrangeiro ${ }^{44}$.

A competência do parlamento para referendar o tratado funciona como condição suspensiva para a sua eficácia plena. É o que claramente se conclui do artigo 49 da Constituição, que dispõe sobre a competência exclusiva do Congresso Nacional para resolver definitivamente sobre tratados, acordos ou atos internacionais que acarretem encargos ou compromissos gravosos ao patrimônio nacional. Isso quer dizer que as isenções em tratados internacionais de impostos dos estados-membros e municípios também passam pelo mesmo processo, não podendo ser ratificados pelos legislativos estaduais e municipais ${ }^{45}$.

A União é uma entidade bifronte no Estado Federal Brasileiro. Este é que é a ordem jurídica total, integrada pelas leis e outros atos normativos da União, Estados, Distrito Federal e Municípios. Dentro desse contexto, as leis da União integram apenas uma ordem jurídica parcial centralizada, ao lado das leis dos Estados e Municípios, estruturantes das ordens parciais locais ou descentralizadas. Só no âmbito do direito interno que se insere a vedação do artigo 151, III, da Constituição, de se instituir através de lei complementar federal isenções de impostos estaduais e municipais ${ }^{46}$.

$\mathrm{Na}$ ordem internacional, o caráter bifronte da União se acentua. As limitações constitucionais ao poder de tributar só cobram sentido rigoroso no âmbito das relações internas entre a União, Estados-membros, Distrito Federal e Municípios. Não é razoável esperar que um tratado internacional crie discriminações internas contra as regras constitucionais sobre a competência tributária estadual e municipal. Os tratados internacionais, como as leis em geral, são feitos para o que normalmente acontece. Um

\footnotetext{
${ }^{44}$ Ibid., p. 242.

${ }^{45}$ Ibid., p. 284.

${ }^{46}$ Ibid., p. 286, 287.
} 
tratado internacional não irá normalmente dispor, mesmo em caráter nacional, sobre coleta de lixo domiciliar, assunto de peculiar interesse dos Municípios ${ }^{47}$.

Um dos objetivos fundamentais da República Federativa do Brasil (não da União) é a integração política, social e cultural dos povos da América Latina, visando à formação de uma comunidade latino-americana de nações ( $\mathrm{CF} / 88$, art. $4^{\circ}$, parágrafo único). Esse dispositivo viabiliza o Mercado Comum do Sul (Mercosul). Para que isso ocorra, não se pode dar aos Estados e Municípios o poder de inviabilizar tratados internacionais que concedam isenções de tributos estaduais e municipais ${ }^{48}$.

Quando um órgão da União subscreve um tratado isso não significa que Estados e Municípios são pré-excluídos dos vínculos decorrentes da sua celebração. O contrário é o que ocorre, como deixa clara a Constituição no artigo $5^{\circ}, \S 2^{\circ}$. Quem celebra o tratado é a República Federativa do Brasil, e, portanto, Municípios, Estados e União são vinculados a ele. Logo, não se trata de isenção heterônoma, e sim, autônoma, pois quem isenta é a Federação como um todo, e tal isenção é de caráter plurilateral e de direito interestatal ${ }^{49}$.

\section{ANÁLISE DE ALGUNS CASOS DA JURISPRUDÊNCIA SOBRE OS LIMITES À CONCESSÃO DE ISENÇÕES}

Será feita agora análise de alguns casos em que as discussões travadas disseram respeito tanto à concessão de isenções como o afastamento das mesmas pela jurisprudência dos tribunais superiores. Os casos selecionados guardam pertinência com os assuntos considerados antes.

Como observação preliminar ao primeiro caso, é constatado que as unidades federativas têm expedido unilateralmente leis e outros atos normativos outorgando vantagens que afetam a carga impositiva, tais como: a) fiscais, que envolvem isenção de

\footnotetext{
${ }^{47}$ Ibid., p. 288, 289.

${ }^{48}$ Ibid., p. 289.

${ }^{49}$ Ibid., p. 293.
} 
impostos para novas empresas por determinado período de tempo, isenções e reduções para micro e pequenas empresas e para situações e produtos específicos e prorrogação dos prazos de pagamento; b) financeiras, para aquisição de ativos fixos, financiamento do pagamento do imposto, participação acionária, financiamento para o desenvolvimento tecnológico e do turismo, formação ou recomposição de capital de trabalho; c) estímulo para infraestrutura, que consiste na venda de lotes e galpões por preços reduzidos, permuta de terrenos para a localização de empresas, doação de áreas industriais e implantação das mesmas; d) outros estímulos, como a simplificação do registro das empresas e das licitações para as pequenas empresas, assistência técnica na elaboração do projeto e apoio à capacitação de pessoas ${ }^{50}$.

$\mathrm{Na}$ Ação Direta de Inconstitucionalidade $n^{0}$ 1308-4 o Supremo Tribunal Federal (STF) confirmou o entendimento de que a concessão unilateral, por Estado-membro ou pelo Distrito Federal, de isenções, incentivos e benefícios fiscais relativos ao Imposto sobre a circulação de mercadorias e serviços (ICMS), sem a prévia celebração de convênio intergovernamental, nos termos da Lei Complementar Federal, afronta o artigo $155, \S 2^{\circ}$, XII, g, da Constituição Federal, e declarou inconstitucional lei gaúcha que concedia isenção em serviço de transporte efetuado mediante concessão ou permissão do Estado do Rio Grande do $\mathrm{Sul}^{51}$. Em outras decisões o STF tem reiterado esse entendimento $^{52} 5354$. O objetivo é evitar a guerra fiscal entre os Estados ao arrepio das

\footnotetext{
${ }^{50}$ Melo, José Eduardo Soares de. ICMS: teoria e prática. $11^{\text {a }}$ ed. São Paulo: Dialética, 2009, p. 339, 340. ${ }^{51}$ BRASIL. Supremo Tribunal Federal. Ação Direta de Inconstitucionalidade no 1308-4. Relator: Min. Ellen Gracie. Julgamento: 12/05/2004. Publicado DJ 04/06/2004. Brasília: Supremo Tribunal Federal, 2004. Disponível em: $<\underline{\text { http://www.stf.jus.br/portal/peticaoInicial/verPeticaoInicial.asp?base }=\text { ADIN\&s1 }=\text { ICMS\&processo }=130}$ 8 > Acesso em: 24 jan. 2014.

${ }^{52}$ BRASIL. Supremo Tribunal Federal. Ação Direta de Inconstitucionalidade $\mathbf{n}^{0}$ 2688. Relator: Min. Joaquim Barbosa. Julgamento: 01/06/2011. Publicado DJ 26/08/2011. Brasília: Supremo Tribunal Federal, 2011. Disponível em: $<$ http://www.stf.jus.br/portal/peticaoInicial/verPeticaoInicial.asp?base=ADIN\&s1=guerrafiscal\&processo $=3674>$ Acesso em: 24 jan. 2014 .

${ }^{53}$ BRASIL. Supremo Tribunal Federal. Ação Direta de Inconstitucionalidade no 3674. Relator: Min. Marco Aurélio de Melo. Julgamento: 01/06/2011. Publicado DJ 29/06/2011. Brasília: Supremo Tribunal Federal, 2011.
$<$ http://www.stf.jus.br/portal/peticaoInicial/verPeticaoInicial.asp?base=ADIN\&s1=guerrafiscal\&processo =3674> Acesso em: 24 jan. 2014 .

54 BRASIL. Supremo Tribunal Federal. Agravo Regimental no Recurso Extraordinário no 637959/PR. Relatora: Min. Luís Fux. Julgamento: 19/02/2013. Publicado DJ 11/03/2013. Brasília: Supremo Tribunal Federal, 2013. Disponível em: $<$ http://www.stf.jus.br/portal/jurisprudencia/listarJurisprudencia.asp?s1=\%28conv\%EAnio+interestadual \%29\&base=baseAcordaos\&url=http://tinyurl.com/q3xkhy9> Acesso em: 24 jan. 2014.
} 
normas constitucionais e legais, bem como a desobediência ao próprio princípio da legalidade, pois a Constituição estabelece regras para a criação e aprovação de regras, que não devem ser desobedecidas pelos Estados.

O segundo caso selecionado é o da Ação Direta de Inconstitucionalidade sob o $\mathrm{n}^{\mathrm{o}}$ 3260-7. No julgamento desta, o STF considerou inconstitucional lei complementar estadual que isentava os membros do Ministério Público do pagamento de custas judiciais, notariais, cartorárias e quaisquer taxas ou emolumentos por ferir o disposto no artigo 150, inciso II, da Constituição do Brasil, quebrando a igualdade de tratamento entre os contribuintes ${ }^{55}$. Como já foi visto nos capítulos anteriores, não se pode criar isenção apenas para privilegiar certo grupo de pessoas, pois ela precisa atender aos seus fins constitucionais e sociais. A isenção aqui considerada também não passa pelo teste da proporcionalidade por ser inadequada, desnecessária, e não conforme aos princípios constitucionais como o da isonomia.

Mas a própria Constituição regula situações em que a igualdade não é observada de forma rigorosa: quando deve se aplicar a isonomia material, em que se diferencia para favorecer os que estão em posição de desvantagem econômica. O terceiro caso selecionado é o da Ação Direta de Inconstitucionalidade $n^{\circ} 4033$, ajuizada contra o artigo $13, \S 3^{\circ}$, da Lei Complementar 123/2006, que isentou da contribuição sindical patronal as microempresas e empresas de pequeno porte optantes do "Supersimples".

O STF julgou improcedente a Ação acima, com rejeição da alegação de violação da reserva de lei específica para dispor sobre isenção (artigo 150, $\S 6^{\circ}$ da Constituição), uma vez que há pertinência temática entre o benefício físcal e a instituição de regime diferenciado de tributação. A isenção concedida não violou o artigo 146, III, “d”, da Constituição, pois a lista de tributos prevista no texto legal que define o campo de reserva da lei complementar é exemplificativa e não taxativa. $O$ tratamento favorecido da micro e pequena empresa foi elevado à condição de princípio constitucional. $\mathrm{O}$ risco à autonomia sindical foi afastado e não se considerou que tenha sido violada a isonomia,

\footnotetext{
${ }^{55}$ BRASIL. Supremo Tribunal Federal. Ação Direta de Inconstitucionalidade no 3260-7. Relator: Min. Eros Grau. Julgamento: 29/03/2007. Publicado DJ 29/06/2007. Brasília: Supremo Tribunal Federal, ano 2007. Disponível em: $<$ http://www.stf.jus.br/portal/peticaoInicial/verPeticaoInicial.asp?base=ADIN\&s1=custasjudiciais\&proce sso $=3260>$ Acesso em: 24 jan. 2014.
} 
uma vez que não há igualdade relevante entre os sindicatos patronais e os sindicatos de representação de trabalhadores, no que se refere ao potencial das fontes de custeio ${ }^{56}$.

O quarto caso é o do Agravo Regimental no Agravo de Instrumento $\mathrm{n}^{\mathrm{o}}$ 210358/RS, em que o STF considerou que a isenção dada pela União de ICMS em relação à ração animal "concentrado de suíno" a prazo e em função de determinadas condições, anteriormente à atual Constituição, configurou direito adquirido, conforme os Atos das Disposições Constitucionais Transitórias (ADCT), artigo 41, $\S 1^{\circ}$ e $2^{\circ}$, com precedente da Corte, negando provimento ao agravo regimental no agravo de instrumento ${ }^{57}$.

As isenções concedidas mediante tratados internacionais a situações em que normalmente haveria incidência de tributos estaduais e municipais despertam polêmica e às vezes os Tribunais precisam decidir sobre a validade das mesmas, que, conforme já visto, não são consideradas heterônomas. Assim, o quinto caso escolhido é o do Agravo Regimental no Agravo de Instrumento no 764951/BA. Neste, o STF considerou que a importação de bacalhau da Noruega, país signatário do GATT, beneficiada por isenção de ICMS veiculada mediante tratado internacional, é legítima. A jurisprudência tem sustentado a constitucionalidade das desonerações tributárias estabelecidas, por meio de tratado, pela República, máxime no que diz com a extensão, às mercadorias importadas de países signatários do GATT (Acordo Geral sobre Tarifas Aduaneiras e Comércio), das isenções de ICMS concedidas às similares nacionais (Súmula STF 575). Considerou-se descabido analisar, em sede de recurso extraordinário, alegações pertinentes à abrangência e à legitimidade de isenções frente à legislação infraconstitucional, bem como a similaridade entre produtos nacionais e estrangeiros para efeito da outorga do

\footnotetext{
56 BRASIL. Supremo Tribunal Federal. Ação Direta de Inconstitucionalidade no 4033. Relator: Min. Joaquim Barbosa. Julgamento: 15/09/2010. Publicado DJ 07/02/2011. Brasília: Supremo Tribunal Federal, 2011. Disponível

em: $<$ http://www.stf.jus.br/portal/peticaoInicial/verPeticaoInicial.asp?base=ADIN\&sl=contribuição sindical patronal\&processo=4033> Acesso em: 24 jan. 2014 .

${ }^{57}$ BRASIL. Supremo Tribunal Federal. Agravo Regimental no Agravo de Instrumento no 210358/RS. Relator: Min. Sepúlveda Pertence. Julgamento: 06/12/2005. Publicado DJ 03/02/2006. Brasília: Supremo Federal, 2006. Disponível $<$ http://www.stf.jus.br/portal/jurisprudencia/listarJurisprudencia.asp?s1=\%28ra\%E7\%E3o+animal\%29\&b ase=baseAcordaos\&url=http://tinyurl.com/otlk79u $>$ Acesso em: 24 jan. 2014.
} 
tratamento isonômico exigido pelo GATT. O Tribunal fez aplicação da Súmula STF 279 e julgou pelo não provimento do Agravo regimental ${ }^{58} 59$.

O caso abaixo é relacionado com o princípio da legalidade e do devido processo legal no campo das isenções. O contribuinte tem direito a usufruir isenção se ele satisfez os requisitos de norma que venha a ser posteriormente revogada, não devendo ser prejudicado se não deu causa a circunstâncias que poderiam porventura ter como efeito a perda do benefício.

No julgamento do Recurso Especial $n^{\circ}$ 1.214.882/SP, o Superior Tribunal de Justiça (STJ) considerou que, mesmo que o desembaraço aduaneiro, que é fato gerador do IPI (conforme o artigo 46, I, do CTN, combinado com os artigos 23 e 44, do DecretoLei n. 37/66), ocorra em data posterior à revogação do benefício fiscal do artigo 17, II, do Decreto-Lei n. 2.433/88, pelo art. $1^{\circ}$, da Lei n. 8.03290, a eficácia da norma de isenção resta garantida pelo art. 10, II, da mesma lei. No caso concreto o contribuinte desempenhava a atividade de editora e importou equipamentos (cilindros de contrapressão) e acessórios (peças de reposição) para integrar o seu ativo fixo, destinando-se à impressão de periódicos. A guia de importação foi emitida em 19.09.1989, no entanto a mercadoria somente deu entrada no porto de Santos em 18.04.1990 (desembaraço aduaneiro), portanto a guia foi emitida antes da entrada em vigor da lei que extinguiu a isenção. O que se discutiu foi o seu enquadramento ou em norma de isenção do IPI. O Recurso especial interposto pela Fazenda não foi provido ${ }^{60}$.

O sétimo caso envolveu uma acesa polêmica. No Recurso Especial $\mathrm{n}^{\mathrm{o}}$ 1.013.060/RJ, o STJ, ao analisar possibilidade de isenção de imposto de renda, deu

${ }^{58}$ BRASIL. Supremo Tribunal Federal. Agravo Regimental no Agravo de Instrumento no 764951/BA. Relatora: Min. Rosa Weber. Julgamento: 26/02/2013. Publicado DJ 13/03/2013. Brasília: Supremo Tribunal Federal, 2013. Disponível em: $<$ http://www.stf.jus.br/portal/jurisprudencia/listarJurisprudencia.asp?s1=\%28isen $\% \mathrm{E} 7 \% \mathrm{E} 3 \mathrm{o}+$ heter\%F4no ma\%29\&base=baseAcordaos\&url=http://tinyurl.com/oklu3wa $>$ Acesso em: 24 jan. 2014.

59 No mesmo sentido: BRASIL. Supremo Tribunal Federal. Agravo Regimental no Agravo de Instrumento $\mathbf{n}^{\mathbf{0}}$ 543943/PR. Relatora: Min. Celso de Melo. Julgamento: 30/11/2010. Publicado DJ 15/02/2011. Brasília: Supremo Tribunal Federal, 2011. Disponível em: $<$ http://www.stf.jus.br/portal/jurisprudencia/listarJurisprudencia.asp?s1=\%28isen $\% \mathrm{E} 7 \% \mathrm{E} 3 \mathrm{o}+$ heter $\% \mathrm{~F} 4 \mathrm{no}$ ma\%29\&base=baseAcordaos\&url=http://tinyurl.com/oklu3wa $>$ Acesso em: 24 jan. 2014.

${ }^{60}$ BRASIL. Superior Tribunal de Justiça. Recurso Especial no 1.214.882/SP. Relator: Min. Mauro Campbell Marques. Julgamento: 17/05/2011. Publicado DJ 30/05/2011. Brasília: Superior Tribunal de Justiça, 2011.

Disponível

em:

$<$ https://ww2.stj.jus.br/revistaeletronica/Abre Documento.asp?sLink=ATC\&sSeq=15146223\&sReg=201 001729130\&sData=20110530\&sTipo=91\&formato=HTML> Acesso em: 24 jan. 2014. 


\section{RE REVTA ACDENMCA

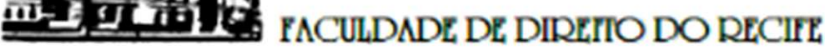

provimento ao pedido da Fazenda por considerar que a "deficiência auditiva sensória neural bilateral profunda irreversível" não era uma moléstia prevista no rol taxativo do artigo $6^{\circ}$, inciso XIV, da Lei ${ }^{0} 7.713 / 88$ e, portanto, não caberia interpretação analógica, pois a cegueira é que foi prevista na norma de isenção, e não a surdez. O Poder Judiciário não deveria assim substituir a vontade do legislador para conceder isenção onde a lei não prevê, sobretudo porque o artigo 111 do CTN somente permitiu a interpretação literal de normas concessivas de isenção. Não se pode considerar que a omissão do legislador em incluir a surdez no rol do artigo $6^{\circ}, \mathrm{XIV}$, da Lei ${ }^{\circ} 7.713 / 88$ tenha sido em razão de falha ou esquecimento e, ainda que esse fosse o caso, não poderia o julgador estender o benefício fiscal à hipótese não contemplada pela norma ${ }^{61}$.

Em voto vencido, porém, se sustentou tese oposta. O artigo 111 do CTN pode trazer ou reclamar uma interpretação taxativa, mas nunca literal. É que, na verdade, é impossível qualquer texto legislativo, sobretudo decorrente de um colegiado com interesses tão distintos, explicitar de forma a não deixar, absolutamente, nenhuma margem àquilo que se pretendeu dispor. E o papel da Justiça é o de ajustar a lei às realidades que se apresentam em decorrência da própria vida. Tanto é assim que, durante muito tempo, era entendido que a cegueira a ser contemplada com a não incidência do imposto de renda seria a cegueira plena, dos dois olhos, até que no Recurso Especial $\mathrm{n}^{\mathrm{o}}$ 1.196.500MT, se entendeu que a cegueira de um só olho era bastante para ser contemplada, em um abrandamento de interpretação mais rigorosa. O caso apresentado é semelhante. A deterioração progressiva dos nervos auditivos leva à paralisia irreversível e incapacitante, atendendo o requisito do artigo $6^{\circ}$, XIV, da Lei ${ }^{\circ} 7.713 / 88^{62}$.

Se fosse levado em consideração que a dignidade humana é o valor supremo da Constituição (apesar de existir polêmica discussão sobre se este valor é mesmo o maior), o voto vencido é o que deveria ter prevalecido, e a decisão do Tribunal a quo não teria

${ }^{61}$ BRASIL. Superior Tribunal de Justiça. Recurso Especial no 1.013.060/RJ. Relator: Min. Mauro Campbell Marques. Julgamento: 10/05/2011. Publicado DJ 08/06/2012. Brasília: Superior Tribunal de Justiça, $2012 . \quad$ Disponível em: $<$ https://ww2.stj.jus.br/revistaeletronica/Abre Documento.asp?sLink=ATC\&sSeq=12902108\&sReg=200 702951340\&sData=20120608\&sTipo=91\&formato=HTML $>$ Acesso em: 24 jan. 2014.

${ }^{62}$ BRASIL. Superior Tribunal de Justiça. Recurso Especial no 1.013.060/RJ. Voto vencido: Min. César Asfor Rocha. Julgamento: 10/05/2011. Publicado DJ 08/06/2012. Brasília: Superior Tribunal de Justiça, 2012. Disponível

em:

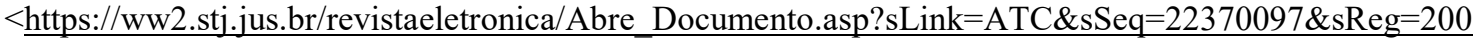
702951340\&sData=20120608\&sTipo=52\&formato=HTML $>$ Acesso em: 24 jan. 2014. 
sido reformada. Vislumbra-se neste caso a possibilidade de se considerar que haveria interpretação extensiva da norma de isenção para abranger a surdez, o que resolveria o problema da alegação de analogia, e atendido estaria o requisito já estabelecido no artigo $6^{\circ}$, XIV, da Lei $n^{0} 7.713 / 88$. A isenção, neste caso, realizaria o postulado da preservação do mínimo existencial, já que as despesas com a moléstia referida são altas, corroendo a renda da pessoa doente.

\section{CONCLUSÃO}

O constitucionalismo consagrou o governo das leis e a separação de poderes. Com isso, erigiram-se os princípios do devido processo legal e da legalidade, que significam a obediência ao procedimento legislativo estabelecido e aos direitos fundamentais, que devem ser considerados na elaboração das leis; também a possibilidade de anulação judicial de normas inconstitucionais que porventura sejam veiculadas pelo legislador. $\mathrm{O}$ princípio do devido processo legal, tanto na sua forma procedimental, quanto no seu aspecto substancial, auxilia o intérprete do direito tributário.

As isenções se submetem ao princípio da legalidade tão quanto às normas criadoras de tributos. Isso garante o respeito à segurança das relações jurídicas e também procura evitar a concessão abusiva das mesmas, pois, ao invés de serem privilégios, só devem ser concedidas no interesse da coletividade, contribuindo para a ampliação dos direitos fundamentais. Até porque quando se concede isenção há o sacrifício daquilo que se deixa de arrecadar, portanto, para que seja legítima, ela precisa trazer um retorno positivo à sociedade.

Os princípios constitucionais, expressos ou implícitos, servem de guia para o intérprete das isenções legais. O princípio da capacidade contributiva deve ser levado em conta, pois apesar da isenção evitar o surgimento da obrigação tributária, é preciso verificar a capacidade econômica dos sujeitos candidatos a serem beneficiários da norma de isenção. O princípio da isonomia, na sua acepção material, significa que as desigualdades que venham a ser criadas pelo legislador devem ser sempre no sentido de 
procurar reduzir as desigualdades existentes no plano fático, logo, não devem ser criadas isenções que desequilibrem para pior a livre concorrência ou que aprofunde as diferenças regionais e sociais.

Os princípios da proporcionalidade e da razoabilidade funcionam como critérios para a orientação do intérprete e para a concordância prática dos dispositivos da Constituição. A razoabilidade serve para que se procure evitar o absurdo. A proporcionalidade dá o passo adicional da análise da adequação meio e fim, da necessidade da medida, e da conformidade com os direitos e princípios fundamentais da constituição. Se uma norma que estabelece isenção não passar por estes testes, ela pode ser considerada inconstitucional.

As isenções podem ser objetivas ou subjetivas, embora as primeiras também em certa medida tenham um grau de subjetividade considerável. Também podem ser condicionadas ou incondicionadas. Em poucos casos será total, pois o CTN estabelece que, salvo disposição legal, as isenções não se aplicam às taxas e às contribuições de melhoria.

As isenções veiculadas por tratados internacionais formam uma modalidade especial em que o Estado brasileiro, representando as três esferas da Federação, assina e ratifica as convenções, convênios e acordos em nome dos três entes. Logo, tal isenção não pode ser considerada constitucionalmente heterônoma, ainda que afete o tratamento jurídico de situações tributárias estaduais e municipais. Se diferente fosse, o Mercosul seria inviabilizado e se instalaria uma grave insegurança jurídica nas relações do comércio exterior.

Na discussão dos casos se percebe que há uma consolidação de diversos conteúdos básicos como a posição dos tratados internacionais, interpretação do princípio da legalidade e aplicação material do princípio da isonomia. Persistem, porém, problemas como o da plena efetivação dos direitos fundamentais quando a interpretação judicial prestigia uma interpretação gramatical da lei ao invés de confrontá-la com os direitos fundamentais da Constituição, bem como continua acesa a polêmica da guerra fiscal entre os Estados, apesar do esforço da jurisprudência em estabelecer balizas para impedir os abusos neste campo. 


\section{REVISTA ACADÊMICA FACULDADE DE DIRETIO DO RECIFE}

A pesquisa constatou que o tema das isenções tributárias é de intensa preocupação jurisprudencial e precisa ser mais explorada pela doutrina, que muitas vezes se concentra na análise das normas que estabelecem obrigações tributárias principais e acessórias, quando a realidade é que as normas que estabelecem tanto as isenções como as imunidades possuem alto grau de importância e relação direta com os direitos fundamentais.

\section{REFERÊNCIAS}

BASTOS, Celso Ribeiro. Curso de Direito Constitucional. 14 a ed. São Paulo: Saraiva, 1992.

BORGES, José Souto Maior. Lançamento Tributário. $2^{\mathrm{a}}$ ed. São Paulo: Malheiros, 1999.

Obrigação Tributária. $2^{\mathrm{a}}$ ed. São Paulo: Malheiros, 1999.

Teoria Geral da Isenção Tributária. $3^{\mathrm{a}}$ ed. São Paulo: Malheiros, 2001.

BRASIL. Ministério da Fazenda - Câmara Superior de Recursos Fiscais. Processo $n^{\circ}$ 10830.000059/96-02. Relatora: Anelise Daudt Prieto. Julgamento: 20/02/2006. Brasília: Câmara Superior de Recursos Fiscais, 2006. Disponível em: $<$ http://www.carf.fazenda.gov.br> Acesso em 15 out. 2014.

Ministério da Fazenda - Câmara Superior de Recursos Fiscais. Processo $\mathbf{n}^{\mathbf{0}}$ 10830.005479/2002-21. Relator: Antônio Carlos Guidoni Filho. Julgamento: 09/03/2009. Brasília: Câmara Superior de Recursos Fiscais, 2009. Disponível em: $<$ http://www.carf.fazenda.gov.br> Acesso em 15 out. 2014.

Superior Tribunal de Justiça. Recurso Especial $n^{0}$ 463.418-SC. Relator: Min. Denise Arruda. Julgamento: 21/11/2006. Publicado DJ 18/12/2006. Brasília: Superior Tribunal de Justiça, 2006. Disponível em: <http://www.stj.jus.br $>$ Acesso em 15 out. 2014.

Superior Tribunal de Justiça. Recurso Especial $n^{0}$ 478.853-RS. Relator: Min. Luiz Fux. Julgamento: 10/06/2003. Publicado DJ 23/06/2003. Brasília: Superior Tribunal de Justiça, 2003. Disponível em: <http://www.stj.jus.br $>$ Acesso em 15 out. 2014.

Superior Tribunal de Justiça. Recurso Especial $n^{0} \mathbf{1 . 0 1 3 . 0 6 0 / R J}$. Voto vencido: Min. César Asfor Rocha. Julgamento: 10/05/2011. Publicado DJ 08/06/2012. Brasília: Superior Tribunal de Justiça, 2012. Disponível em: $<$ https://ww2.stj.jus.br/revistaeletronica/Abre_Documento.asp?sLink=ATC\&sSeq=2237 $0097 \&$ sReg $=200702951340 \&$ sData $=20120608 \&$ sTipo $=52 \&$ formato $=$ HTML $>$ Acesso em: 24 jan. 2014. 
. Superior Tribunal de Justiça. Recurso Especial $n^{0}$ 1.013.060/RJ. Relator: Min. Mauro Campbell Marques. Julgamento: 10/05/2011. Publicado DJ 08/06/2012. Brasília: Superior Tribunal de Justiça, 2012. Disponível em: $<$ https://ww2.stj.jus.br/revistaeletronica/Abre Documento.asp?sLink=ATC\&sSeq $=1290$ $2108 \&$ sReg $=200702951340 \&$ sData $=20120608 \&$ sTipo $=91 \&$ formato $=$ HTML $>$ Acesso em: 24 jan. 2014.

Superior Tribunal de Justiça. Recurso Especial $n^{\circ}$ 1.214.882/SP. Relator: Min. Mauro Campbell Marques. Julgamento: 17/05/2011. Publicado DJ 30/05/2011. Brasília: Superior Tribunal de Justiça, 2011. Disponível em: $<$ https://ww2.stj.jus.br/revistaeletronica/Abre Documento.asp?sLink=ATC\&sSeq $=1514$ $6223 \&$ sReg $=201001729130 \&$ sData $=20110530 \&$ sTipo $=91 \&$ formato $=$ HTML $>$ Acesso em: 24 jan. 2014.

. Supremo Tribunal Federal. Ação Direta de Inconstitucionalidade n ${ }^{0}$ 13084. Relator: Min. Ellen Gracie. Julgamento: 12/05/2004. Publicado DJ 04/06/2004. Brasília: Supremo Tribunal Federal, 2004. Disponível em: $<$ http://www.stf.jus.br/portal/peticaoInicial/verPeticaoInicial.asp?base=ADIN\&s1=ICM

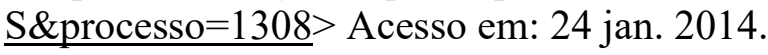

Supremo Tribunal Federal. Ação Direta de Inconstitucionalidade $\mathbf{n}^{\circ} 2688$. Relator: Min. Joaquim Barbosa. Julgamento: 01/06/2011. Publicado DJ 26/08/2011. Brasília: Supremo Tribunal Federal, 2011. Disponível em: $<$ http://www.stf.jus.br/portal/peticaoInicial/verPeticaoInicial.asp?base=ADIN\&s1=guer ra fiscal\&processo=3674> Acesso em: 24 jan. 2014.

Supremo Tribunal Federal. Ação Direta de Inconstitucionalidade no 32607. Relator: Min. Eros Grau. Julgamento: 29/03/2007. Publicado DJ 29/06/2007. Brasília: Supremo Tribunal Federal, ano 2007. Disponível em: $<$ http://www.stf.jus.br/portal/peticaoInicial/verPeticaoInicial.asp?base=ADIN\&s1=custa s judiciais\&processo=3260> Acesso em: 24 jan. 2014.

. Supremo Tribunal Federal. Ação Direta de Inconstitucionalidade no 3674. Relator: Min. Marco Aurélio de Melo. Julgamento: 01/06/2011. Publicado DJ 29/06/2011. Brasília: Supremo Tribunal Federal, 2011. Disponível em: $<$ http://www.stf.jus.br/portal/peticaoInicial/verPeticaoInicial.asp?base=ADIN\&s1=guer ra fiscal\&processo=3674> Acesso em: 24 jan. 2014.

. Supremo Tribunal Federal. Ação Direta de Inconstitucionalidade no 4033. Relator: Min. Joaquim Barbosa. Julgamento: 15/09/2010. Publicado DJ 07/02/2011. Brasília: Supremo Tribunal Federal, 2011. Disponível em: $<$ http://www.stf.jus.br/portal/peticaoInicial/verPeticaoInicial.asp?base=ADIN\&s1=contr ibuição sindical patronal\&processo=4033> Acesso em: 24 jan. 2014.

. Supremo Tribunal Federal. Agravo Regimental no Agravo de Instrumento

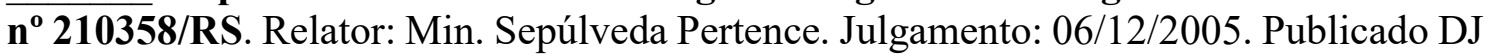
03/02/2006. Brasília: Supremo Tribunal Federal, 2006. Disponível em: $<$ http://www.stf.jus.br/portal/jurisprudencia/listarJurisprudencia.asp?s1=\%28ra\%E7\%E $3 \mathrm{o}+$ animal $\% 29 \&$ base $=$ baseAcordaos\&url $=$ http://tinyurl.com/otlk79u $>$ Acesso em: 24 jan. 2014. 
. Supremo Tribunal Federal. Agravo Regimental no Agravo de Instrumento

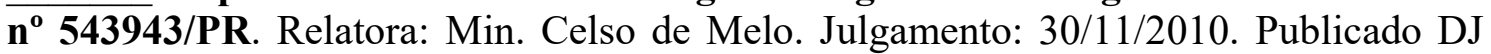
15/02/2011. Brasília: Supremo Tribunal Federal, 2011. Disponível em: $<$ http://www.stf.jus.br/portal/jurisprudencia/listarJurisprudencia.asp?s1=\%28isen $\%$ E7\% E3o+heter\%F4noma\%29\&base=baseAcordaos\&url=http://tinyurl.com/oklu3wa $>$ Acesso em: 24 jan. 2014.

Supremo Tribunal Federal. Agravo Regimental no Agravo de Instrumento $\mathbf{n}^{\mathbf{0}}$ 764951/BA. Relatora: Min. Rosa Weber. Julgamento: 26/02/2013. Publicado DJ 13/03/2013. Brasília: Supremo Tribunal Federal, 2013. Disponível em:

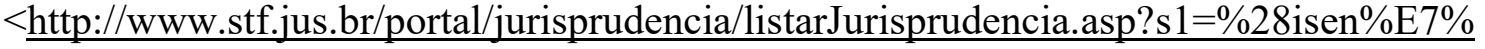
E3o+heter\%F4noma\%29\&base=baseAcordaos\&url=http://tinyurl.com/oklu3wa $>$ Acesso em: 24 jan. 2014.

. Supremo Tribunal Federal. Agravo Regimental no Agravo Regimental no Recurso Extraordinário no $\mathbf{7 1 9 . 8 0 0 / D F}$. Relator: Min. Celso de Mello. Julgamento: 11/06/2013. Brasília: Supremo Tribunal Federal, 2013. Disponível em: $<$ http://www.stf.jus.br> Acesso em: 15 out. 2014.

Supremo Tribunal Federal. Agravo Regimental no Recurso Extraordinário no 637959/PR. Relatora: Min. Luís Fux. Julgamento: 19/02/2013. Publicado DJ 11/03/2013. Brasília: Supremo Tribunal Federal, 2013. Disponível em: $<$ http://www.stf.jus.br/portal/jurisprudencia/listarJurisprudencia.asp?s 1=\%28conv\%EA

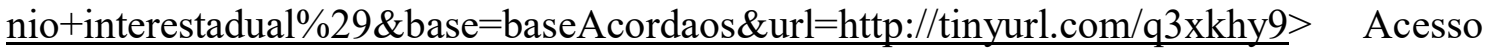
em: 24 jan. 2014.

CANOTILHO, J. J. Gomes. Direito Constitucional e Teoria da Constituição. $4^{\mathrm{a}}$ ed. Coimbra: Almedina, 1997.

MELO, José Eduardo Soares de. ICMS: teoria e prática. 11 a ed. São Paulo: Dialética, 2009.

NOGUEIRA, Alberto. O devido processo legal tributário. Rio de Janeiro: Renovar, 1995.

PIMENTA, Paulo Roberto Lyrio. Contribuições de intervenção no domínio econômico. São Paulo: Dialética, 2002.

VIEIRA, Oscar Vilhena. Direitos Fundamentais: uma leitura da jurisprudência do STF. São Paulo: Malheiros, 2006. 